\title{
The State of Our Democracy ${ }^{1}$
}

\author{
ARCHBISHOP EMERITUS DESMOND TUTU \\ Chancellor, University of the Western Cape and Founding Member of the Board \\ of Trustees, Community Law Centre, U.W.C
}

\section{PREAMBLE}

What a great privilege to have been invited to give this memorial lecture. I was honoured to be numbered among the many friends of dear Dullah Omar and his remarkable wife, Farieda. I first met them soon after becoming General Secretary of the South African Council of Churches in 1978. The Council among several of its programmes had one called Dependants' Conference (DC), referring to the dependants of political prisoners, detainees and banned persons. The Council supported them in various ways with scholarships for their children and helping to transport and support them when they came to visit their loved ones in the maximum security prisons of our land, most often this being Robben Island. The SACC helped with train or airfares, transporting people between Cowley House where they stayed and the Robben Island ferry.

There were wonderful people such as the late Moira Henderson who worked like a Trojan for no pay for DC and the likes of Theresa Solomon, later our Mayor and then our High Commissioner in Canada. Farieda used to provide Cowley House with free vegetables to feed the visitors. The SACC also paid lawyers to act in political trials and for political prisoners in their altercations with prison authorities. Dullah was one of the most conscientious and selfsacrificing of these splendid people and did not endear himself at all to the "system". I remember as if it were yesterday - the excitement in the Omar family when he got a scholarship for a sabbatical at the University of London. It provided for him and his family and everyone was agog. And they had everything ready and then those hard-hearted, callous so and so's, literally on the eve of their departure, gloated to announce that he had been refused a passport. Phew! You cannot imagine the huge disappointment - everyone was deflated. We sat in the Henderson home in Newlands at a loss what to say or do; it was as if the stuffing had been knocked out of us. The "system" was a consummate artist at trying to demoralise us. That was part of the price Dullah and his family paid so that we could today be able to have a lecture on the state of our democracy.

1 Keynote speech delivered at the Fifth Dullar Omar Memorial Lecture, 27 March 2008, at the University of the Western Cape. 
That is not all - Dullah had a heart condition and had medication he took regularly. You all know that the past masters at nefarious deeds of evil planned to substitute his vital medication with something else which would almost certainly have killed him. One of the most magnanimous acts in our land was when this man they had nearly killed piloted through Parliament the Promotion of National Unity and Reconciliation Act which set up the TRC. He was responsible for the legislation that would provide amnesty for the very men who had tried to murder him. He was assisted in drafting this by his dear friend, Dr Alex Boraine, who became the Deputy Chair of the TRC and without whose managerial skills we would have floundered badly in that Commission.

We have been served by some truly great people - people who were remarkable in their dedication to the struggle, selfless and altruistic. Even when he was a Cabinet Minister, Dullah and his family continued to use in Cape Town their relatively modest home. No self-aggrandisement, no self-enrichment for himself or cronies or relatives. His integrity was impeccable and oh, so gentle, not abrasive, quite amazingly soft-spoken. We thank God for giving us Dullah - what an inspiration, what a role model to be emulated by us he has left behind.

\section{WHERE WE COME FROM}

We South Africans are notorious for selling ourselves short. We denigrate our achievements, as if God has somehow shortchanged us out of our national heritage by making us successful. Hey, we are the World Rugby champs - you might not think so from some of our matches in the Super 14, but we have got the Ellis Trophy and the Proteas are the top side in ODI's despite some really embarrassing bungling about selections. Hey, remember where we come from as a country; do you recall that there was a time when police climbed trees to peep into bedrooms, rushing in to check the temperature of the sheets when they thought that that iniquitous piece of legislation, the Immorality Act, might have been contravened, making sordid something that should have been beautiful, love between two persons. Do you recall the demeaning awfulness of the Race Classification Act when we were classified, branded like so many animals? Remember those crude tests to determine a person's race - pushing a comb through the hair, or sticking a pin into you unexpectedly - if you said "Eina” you were coloured - if you said, "Aitchoo", you were Bantu? Do you remember the Mixed Marriages Act - to prevent cohabitation between whites and all those others who were not white?

We have travelled far from that ghastly time of people playing white and avoiding their real family. Children of a darker hue in a white family sometimes committing suicide. Today a black guy walks hand in hand with a white girl and more usually they are in a church and you can't get a razor blade between them and the last time I looked the sky was still firmly in place. A mixed couple will now push a pram with a baby inside of decidedly indeterminate hue. 
In 1986, when I became Archbishop, it was a criminal offence for my family and me to live in Bishopscourt. I said publicly, "This is the Archbishop's residence, I am Archbishop. I intend to occupy my official residence. I am not asking for permission and the government can jolly well do what it chooses." They mercifully did nothing. Now people are surprised when you tell of such oddities, for we no longer subject people to such stupid humiliations. Our children can go to any school. We can live in non-racial suburbs as mixed ethnically as you can get. We no longer see long lines of black men manacled together because they did not have a proper pass. People are not detained without trial and then dying mysteriously in detention.

In the bad old days an all-white Parliament was supreme and could pass any law. Why, they even passed laws which made it an offence for a man to sleep with his own wife if he happened to be a migrant worker living in a single sex hostel and she had the cheek to visit him there; legal but so abominably immoral. Today in our beautiful land it is the Constitution that has the last word and our highest court, the Constitutional Court, can strike down any piece of legislation which it declares unconstitutional - we could not have Parliament pass a law to bring back the death penalty, for instance. Our Constitution has been hailed as one of the most liberal and greatly admired. It has outlawed discrimination on virtually every ground, belief, gender, sexual orientation, disability, age. We have public institutions to safeguard our hard-won liberties and rights, e.g. the Public Protector, the Human Rights Commission, the Gender Commission - of course some are more effective than others. A constitution might not be worth the paper on which it is written, but we do have these inalienable rights enshrined in a Bill of Rights, and it is our business to claim them. We have an independent judiciary and we must guard that independence jealously because it is one of the bulwarks against abuse of power by the executive arm of government. We have a free press which has proved to be a vigilant watchdog and an important institution of civil society. Sadly, we cannot say the same about our public broadcaster which has far too frequently been sycophantic and reminiscent of the SABC of old, so much an echo of His Master's Voice. It has a crucial role especially in a land where many are still illiterate and depend on the radio and TV.

We have had a vibrant civil society, perhaps less active than in the struggle years largely, because overseas donors have tended to channel funds to the government. Lively NGOs are vital for a healthy democracy, and we do have some notable examples - TAC forced a reluctant government to make ARV's more accessible as a right and, very recently, ACCESS gained an important victory enabling beneficiaries to access child grants using identification documents other than those issued by Home Affairs.

Yes, we have amazed the world with a relatively peaceful transition from apartheid to democracy and we have been the flavour of the month because of the extraordinary TRC process. Yes, an awful pariah metamorphosed into the beautiful butterfly of a remarkably stable, multiracial South Africa with a polyglot anthem and eleven, not just two, official languages. And in moments 
such as when we celebrated our World Rugby Cup victory we have shown what we can be - a rainbow nation celebrating, glorying in our rich diversity.

We have much to be proud of - let's stand up and walk tall because of all these and many other achievements.

\section{BUT.....}

What is the state of our democracy? Is a question that requires a scrutiny that examines the shadow side of our life. We must be honest and say that there is a great deal that saddens us, because a lot of it is totally unnecessary.

We are being devastated by the HIV/AIDS pandemic and many lives have been lost totally unnecessarily because we had a bizarre policy. Mercifully, now we have become more orthodox and lives are being saved; people are able, with medication, to lead reasonably normal lives. It could have happened a great deal sooner had we been willing to make our rulers more accountable to their electorate.

There was a good reason at a delicate stage of our transition to emphasise proportional representation. Perhaps we could still have elements of this but surely the time has come to scrap party lists. We should now have constituencies electing their representatives directly. The party list basically turned parliamentarians into voting cattle. You won't be too awkward asking embarrassing questions of the Executive if you want preferment, and so party lists are a sure recipe for kow-towing - only very rarely would Parliament do what it is meant to do: keep the Executive on their toes. I think, too, that the people should be able to vote directly for their President, then we might be spared the tensions of two centres of power.

We must admit that we do have very serious problems. Nearly all admit what I was sharply criticised for pointing out in my Mandela Lecture, that BEE has largely benefited a small elite that kept being recycled. We can no longer pretend that corruption is not a serious problem. We need to do something about the arms deal. We owe it to those who paid a heavy price for our freedom, we owe it to ourselves, we owe it to our future that a thorough, independent judicial inquiry happens as a matter of urgency. It is not going to go away. We warned as a Church that the enemies we were facing were not military but poverty, disease, unemployment, homelessness - to buy sophisticated machines we did not need, for which we did not have the trained personnel would be laughable if it were not so serious.

We must deal vigorously with corruption. It will ignite a conflagration we cannot easily control when the people lose their patience, when they wallow in their squalor, hunger, disease, ugly shacks, and they see so many become so affluent so quickly. The TRC in its final report warned that if the gap between the rich and the poor was not narrowed quickly we might as well kiss reconciliation goodbye. We are sitting on a powder keg.

I believe in affirmative action. It is a moral imperative that suitably qualified persons who were denied certain positions because of their race should be given a head start. But it must be, "suitably qualified". We give affirmative 
action a very bad name when clearly under-qualified persons are appointed to positions where they are as sure as anything going to fail because perhaps their only qualification is their political affiliation. It will fill those who want to see us fail with glee. We must not pour petrol on an already volatile situation and we should take seriously things said apparently in jest, "Previously I was not white enough, now I am not black enough". The resentments those words reveal augur ill for our land.

We must deal urgently and effectively with our very serious crime situation. It is filling people with anxiety and apprehensiveness. Many of our police are doing a sterling job: they need better pay, better working conditions, better training. I think there is nothing to beat visible policing. We all tend to behave better when we see evidence of the arm of the law. Cape Town is cutting its crime rate with its mounted police. In our suburb, Milnerton, the small crime watch cars have helped to reduce the crime rate. We must not let the criminals take over our land. Let us reclaim it.

Our education faces serious problems. Bantu Education has left us a pernicious legacy. We should help teachers recover their morale. UWC and other institutions are helping with improving the qualifications of our teachers. They should be suitably remunerated. They are a critical element in the preservation of our democracy. We went to high schools that were badly equipped. We had four classes in one church building, each in a different corner and sometimes another teacher's lessons were more interesting then your own, and you listened to them rather than your own. We had no desks. The amenities were really nonexistent. In six years I went only twice to the lab. But, boy, were our teachers inspiring! They were, and are today too, absolutely critical if we are to turn our education round. It is in a bad way with some saying that $80 \%$ of our schools are dysfunctional. The communities must own their schools too.

Sadly, we have continued a mindset that was appropriate for fighting apartheid whose laws were immoral and so not obliging obedience. Thus we made South Africa ungovernable. We are by and large still not what we should be now, law-abiding citizens, because these are our laws made by our representatives. Very few of us obey all the traffic laws; just look at how we speed, and the resulting carnage is not surprising. We are all guilty but I think our taxis take the cake, they speed, they open a new lane where none should exist, they swing into moving traffic because they jump the queue which happens far too often when there is a line of cars, and some of us drive past and then force our way in - road rage should happen more frequently; and have you seen those who let a child stand against the dashboard or be carried by a passenger in the front seat without wearing seatbelts? They probably want their child to fly through the windscreen. And why do we litter so much?

You know, I think I know. We have been damaged by apartheid more than we imagined and we, especially black people, have a damaged and low self esteem. This in part does explain he horrendous loss of reverence for life so that there can be so much violence, rape even of babies. Deep down it may be we are saying we don't count for much and so we show it by our attitudes 
to one another and to the environment. We blacks need Black Consciousness and whites might need White Consciousness, then we might avoid the Skielik and the Reitz Hostels of our land - when we have a deep reverence for ourselves and so for others. Rights involve responsibilities obligations. They are two sides of the same coin. I have a right to strike but I have an obligation not to infringe the rights of others. I have no right to trash our streets or public property.

I must just end by saying that if I were Minister of Housing, I would demolish all those eyesores, the RDP Unos and Smarties, and start again. They are the next generation of slums. Look at the houses Niall Mellon and Habitat for Humanity are building. Our people suffered much and deserve a great deal better. Thank God our Minister of Housing is putting up much better structures.

I plead too for the return of the spirit of vigorous debate in a civil discourse. One has nostalgia for the bad old days for one thing - people argued, debated and asked, "Where did you get the mandate?" Now we try to intimidate and think shouting down is debate. My father used to say, "Improve your argument, don't raise your voice."

\section{CONCLUSION}

We have a wonderful land with immense potential. We are going to succeed because God wants us to succeed. We must succeed to demonstrate that a rainbow nation is viable and possible. 